\author{
M. Artwohl · C. Fürnsinn · W. Waldhäusl • \\ T. Hölzenbein · G. Rainer • A. Freudenthaler • \\ M. Roden - S. M. Baumgartner-Parzer
}

\title{
Thiazolidinediones inhibit proliferation of microvascular and macrovascular cells by a PPARy-independent mechanism
}

Received: 9 July 2004 / Accepted: 7 November 2004 / Published online: 24 February 2005

(C) Springer-Verlag 2005

\begin{abstract}
Aims/hypothesis: This study evaluated the hypothesis that peroxisome proliferator-activated receptor- $\gamma$ (PPAR $\gamma$ ) agonists, including thiazolidinediones (TZDs) and the rexinoid LG100268 (LG), directly affect human vascular cell function (proliferation, cell cycle, protein expression, lactate release) independently of (1) their PPAR $\gamma$-activating potential and (2) the cells' vascular origin. Methods: Human umbilical vein endothelial cells (HUVECs), human adult vein endothelial cells (HAVECs), human retinal endothelial cells (HRECs) and human retinal pericytes (HRPYCs) were incubated (48 h) with $2-50 \mu \mathrm{mol} / \mathrm{l}$ rosiglitazone (RSG), RWJ241947 (RWJ), pioglitazone (PIO), troglitazone (TRO), 15-deoxy- $\Delta^{12,14}$-prostaglandin $\mathrm{J}_{2}\left(\mathrm{PGJ}_{2}\right)$ and LG. Proliferation, cell cycle distribution, protein expression, peroxisome proliferator-activated receptor responsive element (PPRE) transcriptional activity and mitochondrial effects were determined by $\left[{ }^{3} \mathrm{H}\right]$ thymidine incorporation, FACS analyses, western blots, reporter assays and lactate release respectively. Results: In HUVECs, RSG, RWJ, PIO, TRO, PGJ ${ }_{2}$ and LG reduced $(p<0.01)$ proliferation (due to $\mathrm{G}_{0} / \mathrm{G}_{1}$ cell cycle arrest) by up to $23 \%, 36 \%, 38 \%, 86 \%, 99 \%$ and $93 \%$ respectively. The antiproliferative response was similar in
\end{abstract}

M. Artwohl · C. Fürnsinn · W. Waldhäusl · A. Freudenthaler · M. Roden · S. M. Baumgartner-Parzer $(\triangle)$

Department of Internal Medicine III, Clinical Division of Endocrinology and Metabolism, Medical University of Vienna, Vienna, Austria

e-mail: sabina.baumgartner-parzer@meduniwien.ac.at

Tel.: +11-43-1404004368

Fax: +11-43-1404007790

T. Hölzenbein

Department of Surgery, Division of Vascular Surgery,

Medical University of Vienna,

Vienna, Austria

G. Rainer

Department of Ophthalmology, Medical University of Vienna,

Vienna, Austria

M. Roden

1st Medical Department, Hanusch Hospital,

Vienna, Austria
HRPYCs and HAVECs, but was attenuated in HRECs. Whereas $\mathrm{p} 21^{\mathrm{WAF}-1 / \mathrm{Cip} 1}$ and $\mathrm{p} 27^{\mathrm{Kip}}$ were differently affected in HUVECs, all agents reduced $(p<0.05)$ expression of cyclins (D3, A, E, B), cyclin-dependent kinase-2 and hyperphosphorylated retinoblastoma protein. The rank order of the antiproliferative effects of TZDs in HUVECs $(\mathrm{RSG} \approx \mathrm{PIO} \approx$ RWJ $<$ TRO) contrasted their PPRE transcriptional activities $(\mathrm{TRO}<\mathrm{PIO}<\mathrm{RSG}<\mathrm{RWJ})$, but correlated with cellular lactate release. Proliferation inhibition and lactate release were mimicked by rotenone (mitochondrial complex I inhibitor). Conclusions/interpretation: In conclusion, this study suggests that the antiproliferative action of the TZDs in vascular cells is independent of their PPAR $\gamma$-activating and associated insulin-sensitising potential, but could relate to mitochondrial mechanisms.

Keywords Mitochondrial mechanism · PPAR $\gamma$.

Proliferation - Thiazolidinediones · Vascular endothelial cells

Abbreviations bFGF: Basic fibroblast growth factor . HAVECs: Human adult vein endothelial cells - HRECs: Human retinal endothelial cells · HRPYCs: Human retinal pericytes - HUVECs: Human umbilical vein endothelial cells $\cdot$ LG: LG100268 $\cdot \mathrm{PGJ}_{2}:\left(15\right.$-deoxy- $\Delta^{12,14}$ prostaglandin $\mathrm{J}_{2}$ ) · PIO: Pioglitazone - PPAR $\gamma$ : Peroxisome proliferator-activated receptor- $\gamma \cdot$ PPRE: Peroxisome proliferator-activated receptor responsive element - ROT: Rotenone - RSG: Rosiglitazone - RWJ: RWJ241947=MCC-555 - TRO: Troglitazone

\section{Introduction}

Thiazolidinediones (TZDs) improve insulin resistance in patients with type 2 diabetes [1] and are regarded to exert their metabolic effects via activation of peroxisome proliferator-activated receptor- $\gamma$ (PPAR $\gamma)$. Recent data [2] suggest, however, that the TZDs' hypoglycaemic actions do not only relate to PPAR $\gamma$ activation, but also to mitochondrial mechanisms at the level of complex I of the respiratory chain, 
resulting in increased anaerobic glycolysis (i.e. lactate release) and loss of cellular energy charge.

By their metabolic action, TZDs can indirectly protect the vascular endothelium against metabolic damage and thus beneficially affect the development of late diabetic microvascular and macrovascular complications.

Recent experimental studies, however, suggest that TZDs and other PPAR $\gamma$ activators also directly affect vascular cell function by modulation of vascular cells' secretory profile [3-7] as well as of their proliferative [8-12] and inflammatory response $[6,7,13]$.

Whether such direct vascular TZD action depends on cell type (microvasculature vs macrovasculature) and PPAR $\gamma$ activation or relates to PPAR $\gamma$-independent [14] mitochondrial $[2,15]$ mechanisms remains to be elucidated.

Therefore, this study tested the hypothesis that direct effects of TZDs on human vascular cell functions are independent of (1) these agents' PPAR $\gamma$-activating potential and insulin-sensitising activity and (2) the cells' vascular origin. To this end, we studied the influence of the naturally occurring PPAR $\gamma$-activator 15 -deoxy- $\Delta^{12,14}$-pros-

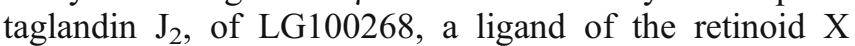
receptor (RXR; which forms heterodimeric complexes with PPAR $\gamma$ ) and of different TZDs (rosiglitazone, pioglitazone, troglitazone and RWJ241947=MCC-555 [16]) on human fetal and adult venous and retinal endothelial cells as well as retinal pericytes to access proliferation and the associated protein expression, PPAR $\gamma$-dependence and mitochondrial function.

\section{Subjects and methods}

Reagents Reagents were from Sigma (St. Louis, MO, USA) if not stated otherwise.

Cell culture Human umbilical vein endothelial cells (HUVECs), isolated and cultured as described previously [17-19], were used as individual isolates in the first subculture.

Human adult vein endothelial cells (HAVECs) were isolated from excess superficial saphenous veins [19], harvested for bypass procedures and cultured as described for HUVECs [17-19]. Cells were used as individual isolates in second to fifth subculture.

Human retinal endothelial cells (HRECs) and pericytes (HRPYCs): human eyes were obtained from the local eye bank within $20 \mathrm{~h}$ of the donor's death. Preparation and digestion of retinae were performed as described by Grant and Guay [20]. Cell suspensions were plated onto gelatin-coated culture dishes (1) in DMEM supplemented with heparin (Biochrom, Berlin, Germany; $7.5 \mathrm{U} / \mathrm{ml}$ ), penicillin, streptomycin, fungizone, insulin-transferrin-selenite, VEGF (BioSource, Camarillo, CA, USA; $50 \mathrm{ng} / \mathrm{ml}$ ), human serum $(20 \%)$ for HREC cultures, or (2) in EGM-2 bullet medium (BioWhittaker, Verviers, Belgium) for HRPYC cultures. Subcultures were performed using trypsin-EDTA and cultures were purified using Dynabeads (Dynal, Hamburg, Germany) coated with monoclonal antibodies against CD31
(HRECs) or 3G5 cell surface ganglioside (HRPYCs), the latter collected in medium from mouse hybridoma cells CR1814 (American Type Culture Collection, Rockville, MD, USA). Experiments were performed using individual isolates in second to fifth subculture.

Endothelial cells were identified by typical phase contrast 'cobblestone' morphology and by immunofluorescence to von Willebrand factor antigen. Pericytes were characterised by the presence of both $\alpha$ - and F-actin and by immunoreactivity with monoclonal antibody 3G5 [21].

Experimental setup Primary cells were made quiescent by contact inhibition and an overnight starvation period in Medium 199 supplemented with $0.02 \%$ BSA and antibiotics. The cells were trypsinised and replated at a density of 10,000 cells $/ \mathrm{cm}^{2}$ in M199 supplemented with $5 \%$ fetal calf serum (FCS; Hyclone, Logan, UT, USA), heparin and antibiotics. After adherence $(4 \mathrm{~h})$, the cells were preincubated $(2 \mathrm{~h}$ ) with $2-50 \mu \mathrm{mol} / \mathrm{l}$ pioglitazone (PIO), troglitazone (TRO), rosiglitazone (RSG), or LG100268 (LG) (all from Sankyo, Tokyo, Japan), with RWJ241947 (RWJ) (generously provided by Johnson \& Johnson, Raritan, NJ, USA), or with 15-deoxy- $\Delta^{12,14}$-prostaglandin $\mathrm{J}_{2}\left(\mathrm{PGJ}_{2}\right)$, or the complex I inhibitor rotenone (ROT) vs intra-individual control cells (incubated with $\mathrm{DMSO}=$ solvent). After preincubation, vascular cells were stimulated to re-enter the cell cycle by addition of $10 \mathrm{ng} / \mathrm{ml}$ basic fibroblast growth factor (bFGF; Gibco, Paisley, Scotland).

After a final exposure time of $48 \mathrm{~h}$ to the above-mentioned agents, the cells were assayed for proliferation, cell cycle distribution, protein expression and cell numbers. Lactate release and bromodeoxyuridine (BrdU) incorporation were determined after $20 \mathrm{~h}$ of exposure.

Determination of proliferation Cells were exposed to the above-mentioned agents $(2-50 \mu \mathrm{mol} / \mathrm{l})$ vs intra-individual control cells (incubated with $\mathrm{DMSO}=$ solvent) in the presence of $\left[{ }^{3} \mathrm{H}\right]$ thymidine (Amersham Pharmacia, Buckinghamshire, UK; $37 \mathrm{kBq} / \mathrm{ml}$ ). After $48 \mathrm{~h}$, cells were trypsinised, lysed, harvested and the incorporated $\left[{ }^{3} \mathrm{H}\right]$ thymidine was counted as described $[17,19]$. Some experiments were performed in the presence of the PPAR $\gamma$ antagonists BADGE and PD068235 (generously provided by Pfizer, Ann Arbor, MI, USA). Proliferation rates are given as a percentage of the respective intra-individual control cultures (set to $100 \%$ ). Samples were tested in quadruplicates.

High-resolution cell cycle analysis Exposure $(20 \mathrm{~h})$ of HUVECs to the above-mentioned agents $(2-50 \mu \mathrm{mol} / \mathrm{l})$ vs intra-individual control cells (incubated with $\mathrm{DMSO}=\mathrm{sol}-$ vent) was performed in the presence of bromodeoxyuridine (BrdU), applying the BrdU Flow Kit (BD PharMingen, San Diego, CA, USA) according to the manufacturer's instructions. Cells that were actively synthesising DNA (BrdU incorporation) in terms of cell cycle position (7-aminoactinomycin staining) were quantified by two parameter FACS (fluorescence activated cell sorting) analysis. BrdU incorporation determines the percentage of cells that have already passed through $\mathrm{S}$ phase. 
Propidium iodide cell cycle analysis After incubation (48 h) with the different agents on test vs intra-individual control cells (incubated with DMSO=solvent), HUVECs and HAVECs were scraped off the dishes and fixed in ice-cold ethanol $(75 \%)$. Total DNA was stained with propidium iodide $(1 \mu \mathrm{g} / \mathrm{ml})$ and analysed using a FACS Calibur (Becton Dickinson, Heidelberg, Germany) as described previously [18]. Data are given as the percentage of cells residing in each cell cycle phase compared to intra-individual control cells (incubated with $\mathrm{DMSO}=$ solvent).

Western blot analysis After a 48-h incubation period with the agents on test vs intra-individual control cells (incubated with DMSO=solvent), HUVECs were lysed in cold Weinberg Buffer as described [17-19]. Aliquots of $10 \mu \mathrm{g}$ total protein were subjected to SDS polyacrylamide gel electrophoresis and then transferred onto nitrocellulose membranes (Schleicher \& Schüll, Kassel, Germany). Blocking of unspecific binding sites with non-fat dry milk $(5 \%$ in tris-buffered saline) containing $0.05 \%$ Tween-20 (Bio Rad, Hercules, CA, USA) was followed by incubation with primary antibodies (p2 ${ }^{\mathrm{Kip}}, \mathrm{cdk}-2 ; \mathrm{p} 21^{\mathrm{WAF}-1 / \mathrm{Cip} 1}$, cyclins D3 and $\mathrm{B}$ [Transduction Laboratories, Lexington, KY, USA]; cyclins A and E [BD Pharmingen, San Diego, CA, USA];
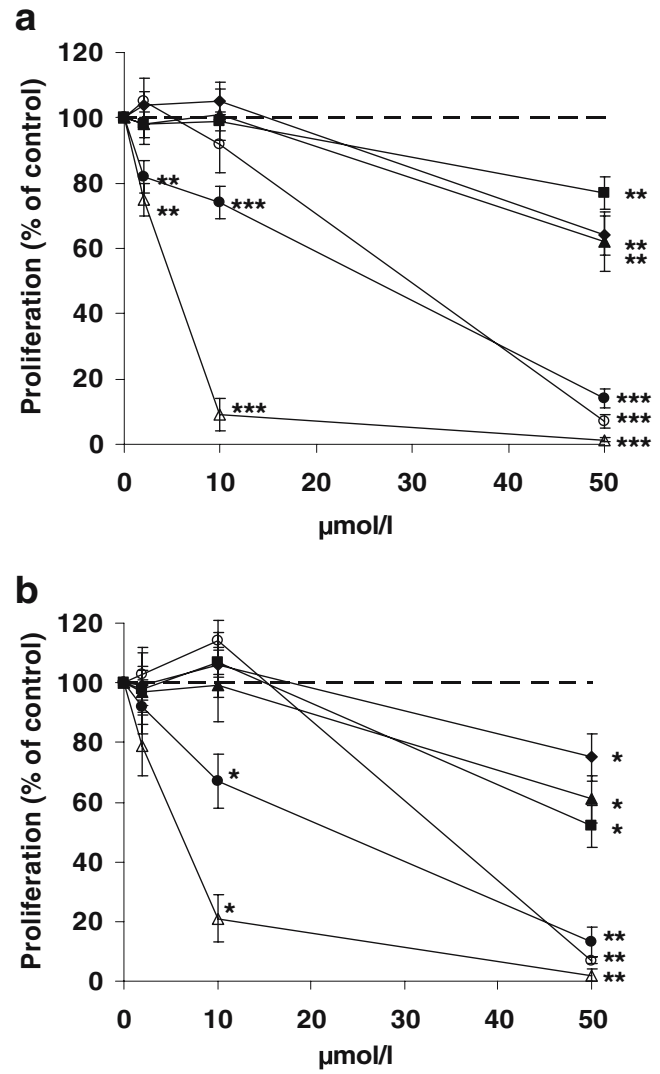

Fig. 1 Proliferation of a HUVECs $(n=8)$ and $\mathbf{b}$ HAVECs $(n=4)$ after exposure to thiazolidinediones, i.e. RSG (black squares), RWJ (black diamonds), PIO (black triangles), TRO (black circles), or to $\mathrm{PGJ}_{2}$ (white triangles) and LG (white circles) vs control $(=100 \%)$. $* p<0.05, * * p<0.01, * * * p<0.001$ vs control
$\mathrm{pRb}$ [Calbiochem, Cambridge, MA, USA]) and detection with horse radish peroxidase-conjugated anti-mouse or antirabbit IgG (Amersham Pharmacia, Buckinghamshire, UK; 1:2,500) using Super Signal Substrate (Pierce, Rockford, IL, USA). Western blots were exposed to Kodak XAR5-Omat films and semiquantitative evaluation of visualised bands on autoradiographies was carried out by densitometry (Gel documentation system; MWG Biotech, Ebersberg, Germany) using Gene Profiler 3.56 for Windows, over multiple exposures, to verify that readings were in the linear range. Results are expressed as differences to intra-individual control cells (incubated with DMSO=solvent, set to $100 \%$ ).

Cell numbers After exposure (48 h) of HUVECs to the above-listed agents vs intra-individual control cells (incubated with $\mathrm{DMSO}=$ solvent), cell numbers were determined using a Beckman Coulter Counter Z2 (Krefeld, Germany). Data are expressed as cell numbers per $60-\mathrm{mm}$ culture dish. a

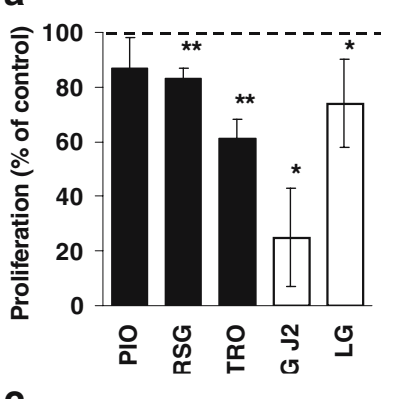

C
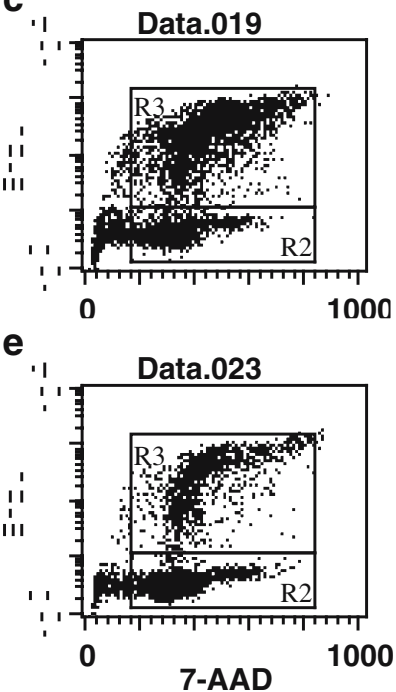

7-AAD

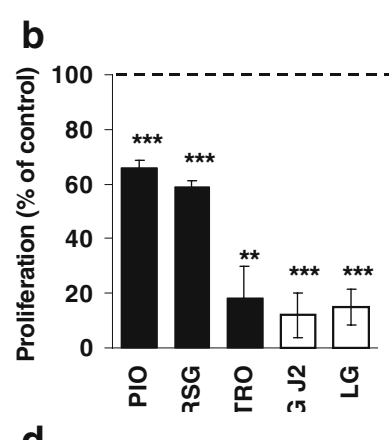

d

Data.024

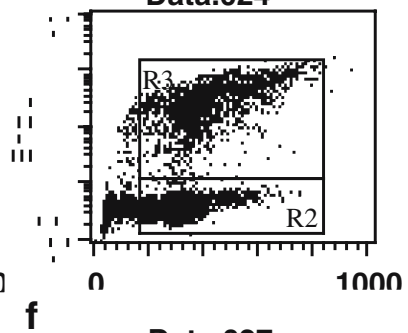

Data.027

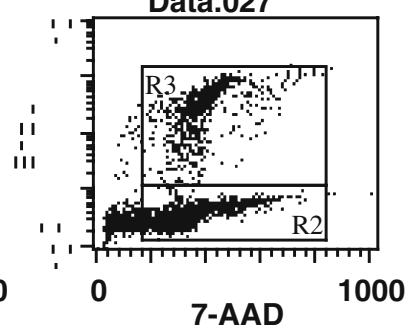

Fig. 2 a, b Proliferation of a HRECs $(n=3)$ and b HRPYCs $(n=3)$ after exposure to $50 \mu \mathrm{mol} / 1$ TZDs (black bars), or PGJ $\mathrm{P}_{2}$ and $\mathrm{LG}$ (white bars) vs control ( $=100 \%$; represented by the broken line). $\mathbf{c}-\mathbf{f}$ Cell cycle reentry of quiescent HUVECs exposed to d RSG, e PIO and $\mathbf{f}$ TRO compared with $\mathbf{c}$ control upon bFGF-stimulation as shown by representative dot plots split in two regions (R2: HUVECs without BrdU incorporation; R3: BrdU-positive HUVECs after passage through $\mathrm{S}$ phase, i.e., having re-entered cell cycle). ${ }^{*} p<0.05$, $* * p<0.01, * * * p<0.001$ vs control 
PPRE transcriptional activity Confluent monolayers of primary HUVECs were trypsinised and seeded into 12well culture plates $(150,000$ cells per well). The next day, HUVECs were transiently co-transfected $(2.25 \mathrm{~h})$ with a peroxisome proliferator-activated receptor responsive element (PPRE) driven firefly luciferase construct $(0.8 \mu \mathrm{g} /$ $\mathrm{ml}$; generously provided by Jörg Leers, Huddinge, Sweden; [22]) and a Renilla luciferase construct $(0.8 \mu \mathrm{g} / \mathrm{ml}$; Promega, Madison, WI, USA; internal control for viability and transfection efficiency) using Lipofectamine Plus (Invitrogen, Carlsbad, CA, USA) according to the manufacturer's instructions (Lipofectamine: $4 \mu \mathrm{l} / \mathrm{ml}$; Plus reagent $8 \mu \mathrm{l} / \mathrm{ml}$ ) in M199. After an overnight equilibration period in full growth medium, HUVECs were exposed $(20 \mathrm{~h})$ to the agents to be tested vs intra-individual control cells (incubated with $\mathrm{DMSO}=$ solvent). After lysis (15 min, passive lysis buffer; Promega, Madison, WI, USA), the activities of both luciferases were measured by means of a dual-luciferase reporter assay system (Promega, Madison, WI, USA) using a Lumat LB 9507 luminometer (Berthod, Bad Wildbach, Germany). Results, which were standardised to Renilla lu-
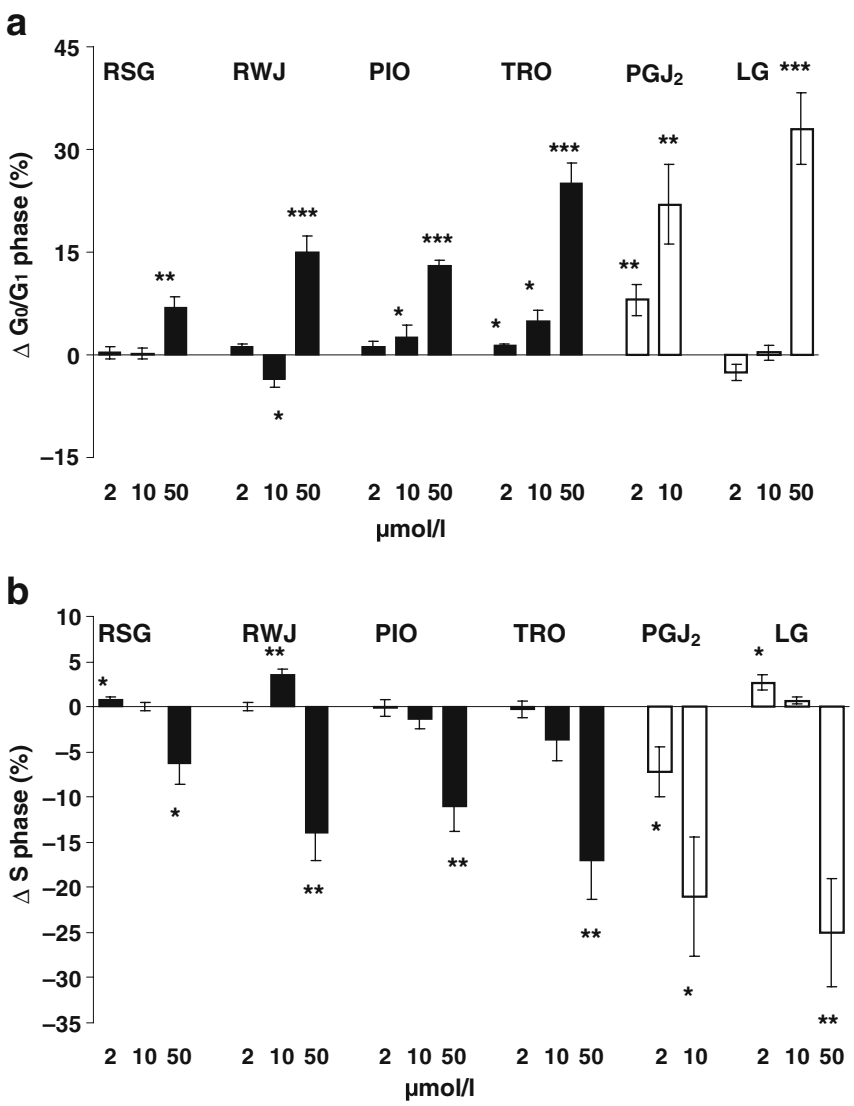

Fig. 3 Percentage of HUVECs $(n=6)$, stimulated (bFGF) to reenter cell cycle, residing in a $\mathrm{G}_{0} / \mathrm{G}_{1}$ phase and $\mathbf{b}$ in $S$ phase after exposure to TZDs (black bars), or PGJ $\mathrm{PJ}_{2}$ and LG (white bars). Data are expressed as differences $(\Delta)$ vs control (i.e. the control has been subtracted from results). Absolute values for control: $53 \pm 5 \%$ of cells were in $\mathrm{G}_{0} / \mathrm{G}_{1}$ phase, $30 \pm 4 \%$ in $\mathrm{S}$ phase and $17 \pm 2 \%$ in $\mathrm{G}_{2} / \mathrm{M}$ phase (the latter being not shown within this figure). ${ }^{*} p<0.05,{ }^{*} * p<0.01$, $* * * p<0.001$ vs control ciferase activity, are expressed as a percentage of the respective intra-individual control cultures (set to $100 \%$ ).

Lactate release Lactate release from HUVECs incubated $(20 \mathrm{~h})$ with/without the respective test agents was determined enzymatically by the lactate dehydrogenase method [23] using $200 \mu \mathrm{l}$ cell culture supernatant. Lactate release was calculated as described [23].

Statistics Data are expressed as means \pm SE. Statistical analysis was performed using paired samples $t$-test (SPSS for Windows 7.5.1). A $p$ value of 0.05 was considered significant.

\section{Results}

Proliferation

Macrovascular cells Proliferation of HUVECs (Fig. 1a) and HAVECs (Fig. 1b) was concentration-dependently reduced by TRO and PGJ ${ }_{2}$, whereas RWJ, RSG and PIO as well as the RXR ligand, LG, inhibited proliferation only at the highest concentration used compared with intraindividual control cultures exposed to DMSO (solvent).

Microvascular cells Proliferation of HRECs (Fig. 2a) and HRPYCs (Fig. 2b), was reduced by $50 \mu \mathrm{mol} / 1 \mathrm{TZDs}, \mathrm{PGJ}_{2}$
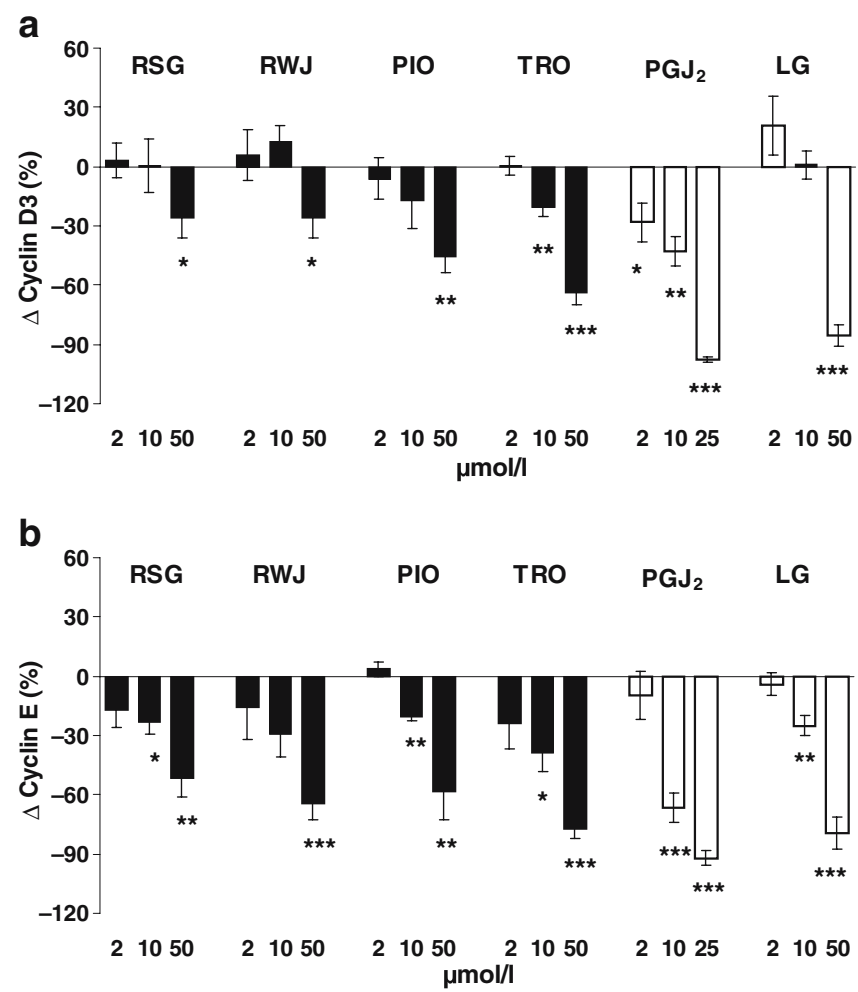

Fig. 4 Protein expression of $\mathrm{G}_{1}$-phase cyclins, i.e. a cyclin D3 and b cyclin E, after incubation of HUVECs $(n=5)$ with TZDs (black bars), or $\mathrm{PGJ}_{2}$ and LG (white bars). Results are expressed as differences $(\Delta)$ vs control $(=100 \%)$. ${ }^{*} p<0.05, * * p<0.01,{ }^{* * *} p<0.001$ vs control 
and LG, showing a more pronounced effect in HRPYCs compared with HRECs.

PPAR $\gamma$ antagonism Addition of up to $10 \mu \mathrm{mol} / 1$ of either PPAR $\gamma$ antagonist, BADGE and PD068235 did not counteract antiproliferative effects of $\mathrm{PGJ}_{2}(10 \mu \mathrm{mol} / \mathrm{l})$ or the different TZDs $(50 \mu \mathrm{mol} / \mathrm{l})$ (proliferation in the presence of antagonists stated as per cent of DMSO-treated control cells, set to $100 \%$ : RSG, $85 \pm 7 \%$; PIO, $47 \pm 6 \%$; RWJ, $46 \pm$ $11 \%$; TRO, $7 \pm 0.6 \%$; $\left.\mathrm{PGJ}_{2}, 6 \pm 0.5 \%\right)$ in HUVECs $(n=4)$. For comparison with proliferation in the absence of antagonists refer to Fig. 1a.

\section{Cell cycle analyses}

Cell cycle re-entry In DMSO-treated control HUVECs $(n=4), 52 \pm 2 \%$ of cells passed through S phase within $20 \mathrm{~h}$ (Fig. 2c), whereas the percentage of cells re-entering cell cycle upon incubation with RWJ $(45 \pm 3 \%, p<0.05)$, RSG $(36 \pm 5 \%, p<0.05$; Fig. $2 \mathrm{~d})$ and PIO $(28 \pm 5 \%, p<0.01$; Fig. 2e) was markedly reduced. TRO $(14 \pm 2 \%, p<0.001$; Fig. $2 \mathrm{f})$, $\mathrm{PGJ}_{2}(7 \pm 1 \%, p<0.01)$ and LG $(8 \pm 2 \%, p<0.01)$ almost completely abolished the number of cells re-entering the cell cycle.

Cell cycle distribution In HUVECs, all substances tested induced an arrest in the $\mathrm{G}_{0} / \mathrm{G}_{1}$ phase (Fig. 3a) of the cell
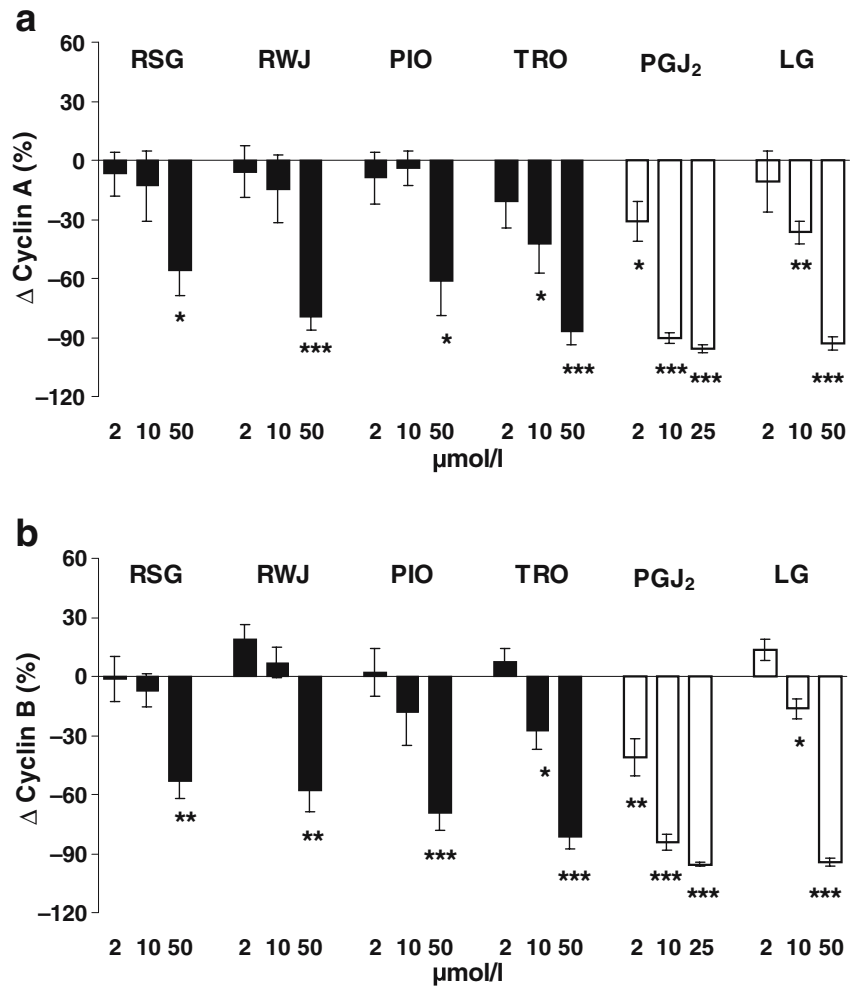

Fig. 5 Protein expression of S-phase and $\mathrm{G}_{2} / \mathrm{M}$-phase cyclins, i.e. $\mathbf{a}$ cyclin $\mathrm{A}$ and $\mathbf{b}$ cyclin $\mathrm{B}$, after incubation of HUVECs $(n=5)$ with TZDs (black bars), or $\mathrm{PGJ}_{2}$ and LG (white bars). Results are expressed as differences $(\Delta)$ vs control $(=100 \%)$. ${ }^{*} p<0.05$, ${ }^{*} p<<0.01$, $* * * p<0.001$ vs control cycle by concomitantly reducing the number of cells residing in $\mathrm{S}$ phase (Fig. 3b). Increasing the concentration of $\mathrm{PGJ}_{2}$ to $50 \mu \mathrm{mol} / 1$ did not further augment these effects (data not shown). Only TRO and LG diminished $(p<0.01)$ the portion of HUVECs in $\mathrm{G}_{2} / \mathrm{M}$ phase (not shown within figures) at the highest concentration used from $17 \pm 2 \%$ to $6.3 \pm 0.7 \%$ and $6 \pm 1 \%$, respectively. Similar results were obtained in four individual isolates of HAVECs (data not shown).

\section{Protein expression}

In HUVECs, TZDs, $\mathrm{PGJ}_{2}$ and $\mathrm{LG}$ reduced protein expression of cyclin $D 3\left(G_{1}\right.$ phase cyclin; Fig. $\left.4 a\right)$, cyclin $E\left(G_{1} / S\right.$ transition; Fig. 4b), cyclin A (S phase cyclin; Fig. 5a) and cyclin $B\left(\mathrm{G}_{2} / \mathrm{M}\right.$ phase; Fig. $\left.5 \mathrm{~b}\right)$ and the cyclin-dependent kinase cdk-2 (forming complexes with the cyclins D3, E and A; Fig. 6a). In parallel, hyperphosphorylation of the retinoblastoma protein (pRb) was markedly reduced (Fig. 6b), whereas a hypophosphorylated band appeared in cells exposed to TZDs, PGJ $_{2}$ and LG (Fig. 7a, autoradiographies).

In HUVECs $(n=5)$, protein expression of the inhibitor of cyclin-dependent kinases (CKI) p $27^{\mathrm{Kip}}$ was exclusively affected by $\mathrm{PGJ}_{2}$ (at $25 \mu \mathrm{mol} / \mathrm{l}:-59 \pm 14 \%, p<0.01$ ), whereas that of $\mathrm{p} 21^{\mathrm{WAF}-1 / \mathrm{Cip} 1}$ (another CKI) was increased by RWJ (at $50 \mu \mathrm{mol} / 1:+137 \pm 48 \%, p<0.05$ ), but reduced by the other agents being tested (at $50 \mu \mathrm{mol} / \mathrm{l}$ : RSG: $-46 \pm 13 \%, p<0.05$;
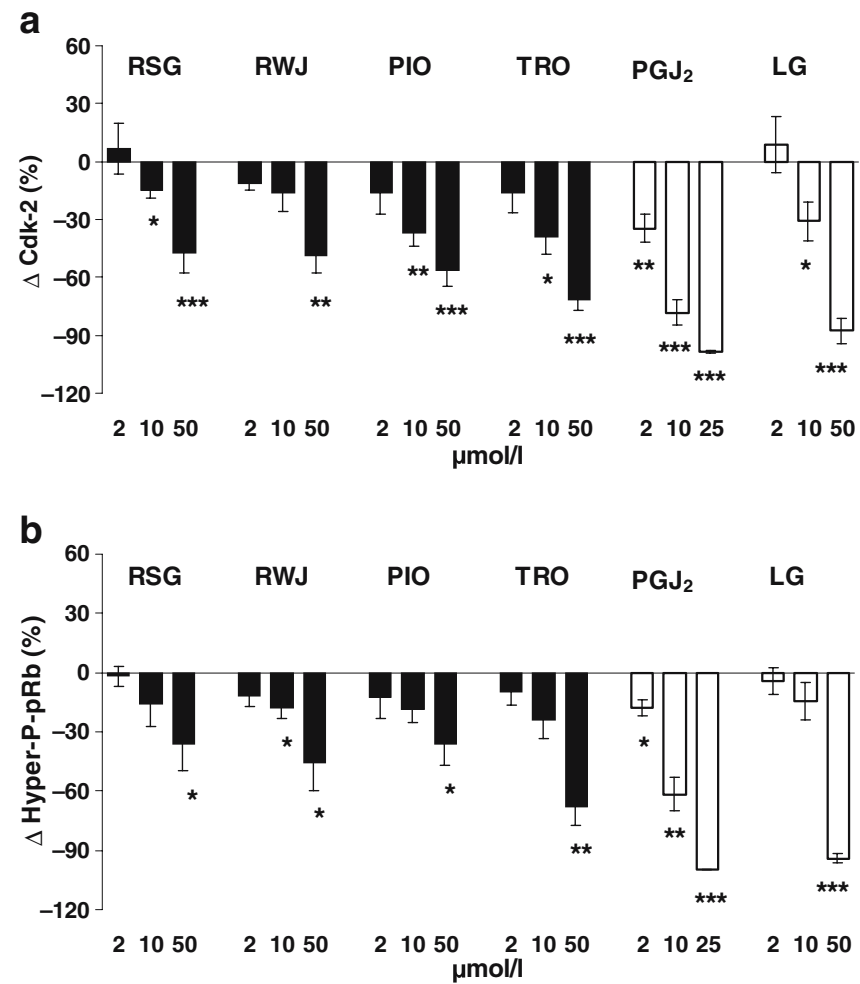

Fig. 6 Protein expression of a cyclin-dependent kinase-2 (cdk-2) and $\mathbf{b}$ hyperphosphorylated retinoblastoma protein $(p R b)$ after incubation of HUVECs $(n=5)$ with TZDs (black bars), or PGJ $\mathrm{J}_{2}$ and LG (white bars). Results are expressed as differences $(\Delta)$ vs control $(=100 \%) .{ }^{*} p<0.05,{ }^{*} p<<0.01,{ }^{* * *} p<0.001$ vs control 

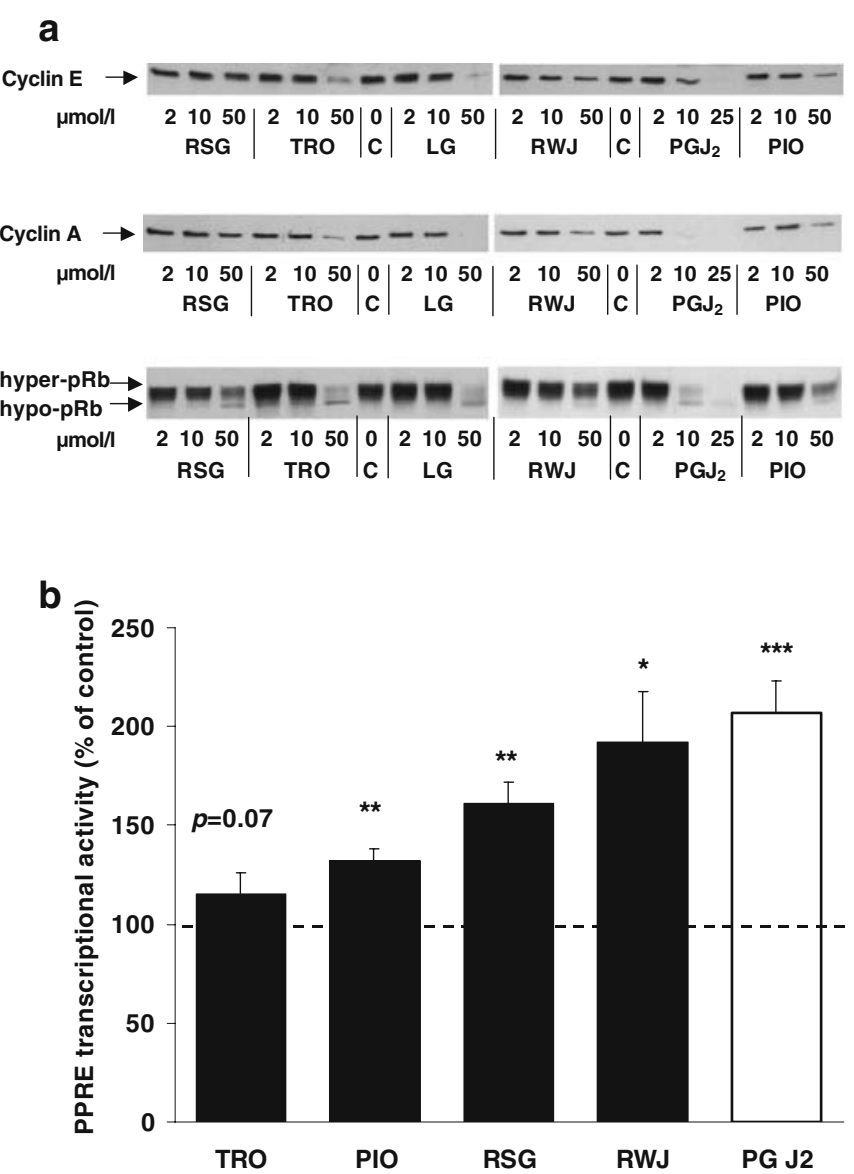

Fig. 7 a Autoradiographies of one representative HUVEC culture showing proteins responsible for $\mathrm{G}_{1} / \mathrm{S}$ transition, i.e. cyclins $\mathrm{E}$ and A and retinoblastoma protein $(p R b) . C$ is the control. b The transcriptional activity of PPRE after exposure of HUVECs $(n=4)$ to TZDs (black bars) or $\mathrm{PGJ}_{2}$ (white bar) $\left(10 \mu \mathrm{mol} / 1\right.$ each). ${ }^{*} p<0.05$, $* * p<0.01, * * * p<0.001$ vs control (set to $100 \%$; represented by the broken line)

PIO: $-47 \pm 10 \%, p<0.01$; TRO: $-44 \pm 10 \%$; $p<0.01$; LG: $-33 \pm 9 \%$, $p<0.05$; at $\left.25 \mu \mathrm{mol} / \mathrm{l}: \mathrm{PGJ}_{2}:-49 \pm 18 \%, p<0.05\right)$ compared with DMSO-treated control cells.

\section{PPRE transcriptional activity}

In HUVECs, $10 \mu \mathrm{mol} / 1$ of TZDs as well as of the natural PPAR $\gamma$ ligand $\mathrm{PGJ}_{2}$ increased PPRE transcriptional activity (Fig. 7b). Incubation with $50 \mu \mathrm{mol} / 1 \mathrm{TZDs}$ and $25 \mu \mathrm{mol} / 1$ $\mathrm{PGJ}_{2}$ did not further increase PPRE activation (data not shown). Addition of $200 \mathrm{nmol} / \mathrm{l}$ of either PPAR $\gamma$ antagonist, BADGE and PD068235, inhibited $\mathrm{PGJ}_{2}$-induced PPRE transcriptional activity by $39 \pm 7 \%$ and by $58 \pm 6 \%$ respectively in two individual HUVEC isolates.

\section{Lactate release}

TZDs as well as rotenone, a specific inhibitor of complex I of the respiratory chain, increased the rates of lactate release from HUVECs (Fig. 8a) and concomitantly reduced

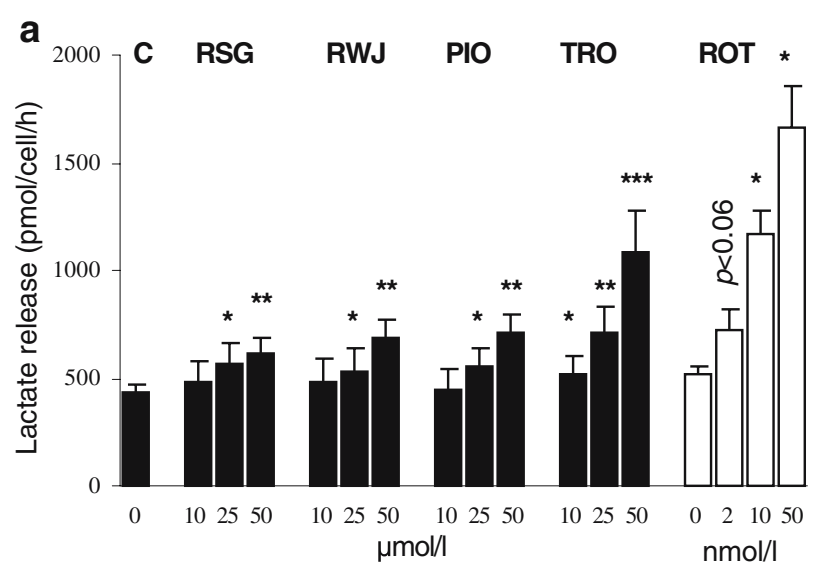

b

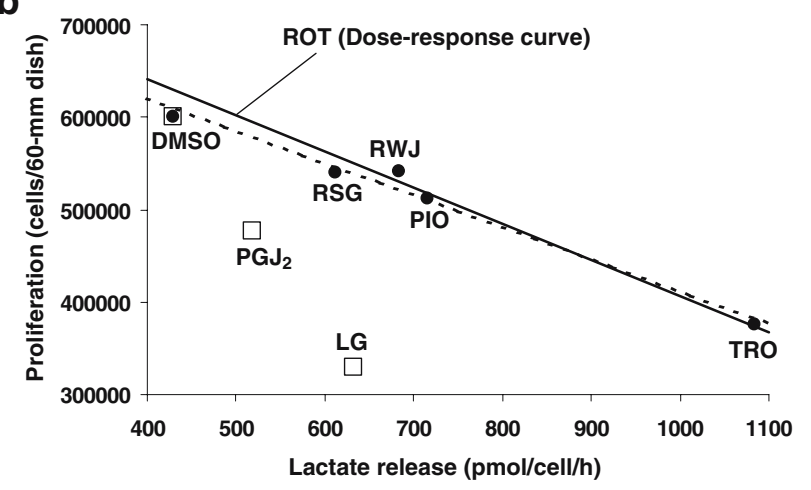

Fig. 8 a Lactate release of HUVECs $(n=5)$ exposed to TZDs (10 $50 \mu \mathrm{mol} / 1$; black bars) or rotenone (ROT) (2-50 nmol/1; white bars). $\mathrm{C}$ is the control. b Proliferation (cell numbers/60-mm dish) inversely correlated with lactate release, independently of whether HUVECs were exposed to rotenone (ROT) (the dose-response curve [0-50 nmol/1] is represented by the black line) or to TZDs (RSG, RWJ, PIO, TRO; $50 \mu \mathrm{mol} / \mathrm{l}$ each), as represented by the dotted line. Neither exposure of HUVECs to $\mathrm{PGJ}_{2}$ nor to LG (white squares) revealed a rotenone-like relationship between lactate production rates and growth arrest. ${ }^{*} p<0.05, * * p<0.01$ vs control

proliferation. In HUVECs, incubated with $\mathrm{PGJ}_{2}$ and $\mathrm{LG}$, inhibition of proliferation did not correlate with lactate release (Fig. 8b, white squares). In endothelial cells exposed to rotenone $(r=-0.998, p<0.01$; Fig. 8 b, black line) and TZDs (at $25 \mu \mathrm{mol} / \mathrm{l}: r=-0.981, p<0.01$, data not shown within figure; at $50 \mu \mathrm{mol} / \mathrm{l}: r=-0.989, p<0.001$; Fig. $8 \mathrm{~b}$, dotted line), however, proliferation inversely correlated with lactate release.

\section{Discussion}

The antiproliferative activities of different PPAR $\gamma$-agonists including four thiazolidinediones (TRO, RSG, PIO, RWJ), the naturally occurring ligand 15 -deoxy- $\Delta^{12,14}$-prostaglandin $\mathrm{J}_{2}$ and a RXR-ligand (LG) were evaluated in human macrovascular cells (HUVECs, HAVECs) and microvascular retinal cells (HRECs and HRPYCs) with respect to cell type specificity and PPAR $\gamma$ dependence.

All the PPAR $\gamma$-agonists tested reduced proliferation in all the cell types studied (HUVECs, HAVECs, HRECs, 
HRPYCs), as has also recently been shown for smooth muscle cells [24]. The naturally occurring ligand $\mathrm{PGJ}_{2}$, the RXR-ligand LG and the thiazolidinedione TRO showed the highest antiproliferative activities, whereas RSG, PIO and RWJ displayed smaller, but comparable potencies with respect to inhibition of proliferation. Compared with HUVECs, HAVECs and HRPYCs, we observed an attenuated antiproliferative activity in human retinal endothelial cells (HREC), especially in response to TRO and LG. Thus, the individual TZD's antiproliferative activity seems to depend on both the respective agent and the specific vascular origin.

The antiproliferative activities of the PPAR $\gamma / \mathrm{RXR}$ agonists observed in human endothelial cells relate to inhibition of the cells' transition from the $\mathrm{G}_{0} / \mathrm{G}_{1}$ phase to the $\mathrm{S}$ phase of the cell cycle, mirrored by the cells' accumulation in $\mathrm{G}_{0} / \mathrm{G}_{1}$ phase. HUVECs exposed to PPAR $\gamma / \mathrm{RXR}$ ligands show diminished cell cycle re-entry as determined by high-resolution cell cycle analyses, being in line with the associated reduction of cyclin D3 expression, which is rate-limiting for S-phase entry $[25,26]$.

In HUVECs, TZDs, $\mathrm{PGJ}_{2}$ and $\mathrm{LG}$ reduced expression of cdk-2 (which forms active complexes with the cyclins D3, E and $\mathrm{A}$ ) and prevented phosphorylation of $\mathrm{pRb}$, as mirrored by reduction of hyperphosphorylated $\mathrm{pRb}$ and appearance of its hypophosphorylated form [27]. Hyperphosphorylated $\mathrm{pRb}$ releases the transcription factor E2F, which, in its free form, induces transcription of cyclins as well as of several DNA replication enzymes [28, 29], whereas hypophosphorylated $\mathrm{pRb}$ binds E2F [30] and thus inhibits cell cycle progression by repressing induction of cell cycle regulatory molecules. TZD-induced reduction of cyclin $\mathrm{E}$ (S-phase cyclin) and $A\left(\mathrm{G}_{2} / \mathrm{M}\right.$-phase cyclin) thus reflect reduction of hyperphosphorylated $\mathrm{pRb}$ and induction of hypophosphorylated $\mathrm{pRb}$, both resulting in cell cycle arrest. Similar mechanisms (e.g. reduced hyperphosphorylation of $\mathrm{pRb}$ ) of the TZDs' antiproliferative actions were previously reported for cultured smooth muscle cells [24, 31].

Protein expression of $\mathrm{p} 27^{\mathrm{Kip}}$ was not affected by TZDs or by LG in HUVECs, suggesting that this inhibitor of cyclin-dependent kinases is of minor importance in endothelial cells' $G_{0} / G_{1}$ cell cycle arrest induced by PPAR $\gamma /$ RXR ligands.

Protein expression of $\mathrm{p} 21^{\mathrm{WAF}-1 / \mathrm{Cip} 1}$ was diminished in HUVECs exposed to PIO, RSG, TRO and $\mathrm{PGJ}_{2}$, but was increased by RWJ. At first glance, the observation of high vs reduced $\mathrm{p} 21^{\mathrm{WAF}-1 / \mathrm{Cip} 1}$ expression, both going along with reduced endothelial proliferation, seems contradictory. It has previously been shown, however, that threshold levels of $\mathrm{p} 21^{\mathrm{WAF}-1 / \mathrm{Cip} 1}$ are necessary for assembly of cyclin-cdk complexes [32] and thus also for cell cycle progression in response to growth factors or mitogens. Indeed, reduced mitogenic stimulation of $\mathrm{p} 21^{\mathrm{WAF}-1 / \mathrm{Cip} 1}$ by RSG and TRO has already been found associated with reduced proliferation in rat aortic smooth muscle cells [31]. On the other hand, upregulation of $\mathrm{p} 21^{\mathrm{WAF}-1 / \mathrm{Cip} 1}$ protein is known to actively repress cell cycle progression by inhibiting the activity of cyclin-dependent kinases [27, 32]. Thus, as observed in the present study, notably both reduced mitogenic stimulation as well as active upregulation of $\mathrm{p} 21^{\text {WAF-1/Cip } 1}$ lead to the same downstream event, i.e. hypophosphorylation of $\mathrm{pRb}$ and, as a consequence, to reduced proliferation.

Since the insulin-sensitising efficacy of TZDs parallels their PPAR $\gamma$ activating potency, it has been assumed that the vascular effects of TZDs also depend on this mechanism $[33,34]$. Recent studies in skeletal muscle [2], however, suggested that mitochondrial mechanisms, independently of PPAR $\gamma$ activation, could also account for the effects of TZDs.

We show that the rank order of the TZDs' PPRE transcriptional activities (TRO $<\mathrm{PIO}<\mathrm{RSG}<\mathrm{RWJ}$ ), reflecting the described PPAR $\gamma$ activating potencies of these substances $[16,35]$, clearly differs from the rank order of the TZDs' antiproliferative effects in HUVECs $(\mathrm{RSG} \approx \mathrm{PIO} \approx \mathrm{RWJ}<$ TRO). Based on these data we suggest that the underlying mechanisms of the TZDs' antiproliferative effects are independent of PPAR $\gamma$ activation. Such hypothesis is corroborated by our findings that the antiproliferative effects of TZDs in HUVECs were not counteracted by the PPAR $\gamma$ inhibitors BADGE and PD068235, although both agents reduced $\mathrm{PGJ}_{2}$-induced PPRE transcriptional activity.

In vitro, in various cell types, TZDs have been shown to inhibit cell respiration and to increase lactate release $[36,37]$. This effect has been attributed to immediate and PPAR $\gamma$-independent inhibition of complex I of the respiratory chain [2] and was suggested as a common mechanism contributing to the TZDs' hypoglycaemic actions [2]. Thus, we evaluated the effects of different PPAR $\gamma$ ligands, including TZDs, on lactate release as an indicator of mitochondrial function in human vascular endothelial cells. In HUVECs exposed to TZDs (but not to $\mathrm{LG}$ and $\mathrm{PGJ}_{2}$ ) proliferation (expressed as cells per $60-\mathrm{mm}$ dish) inversely correlated with the cells' lactate release, indicating impaired mitochondrial function. Our experiments with the specific complex I inhibitor, rotenone, suggest that inhibition of cell respiration, putatively by inhibition of complex I, could mediate the observed antiproliferative action of TZDs. Thus, the TZDs' ability to modulate mitochondrial function obviously not only relates to skeletal muscle [2], canine kidney cells [36] and rat astrocytes [37], but also to human vascular endothelial cells.

In cultured endothelial cells, oxidised LDL has been reported to increase the activity of mitochondrial complex I [38], which is speculated to be the major source of superoxide anions and ROS (reactive oxygen species) in vivo [39]. Increased oxidative stress, mediated by the proatherogenic diabetic milieu, was previously shown to induce endothelial cell dysfunction $[40,41]$ preceding diabetic microangiopathy and macroangiopathy. By direct modulation of endothelial cell mitochondrial function, proliferation and ROS production [39], TZDs could beneficially affect diabetes-associated vascular complications.

The concentrations of TZDs used in this study $(2,10,25$ and $50 \mu \mathrm{mol} / \mathrm{l})$ were comparable to those used in similar experimental studies $[8,9,11,12,42]$ and are (1) within the peak plasma concentrations $(\approx 5 \mu \mathrm{mol} / \mathrm{l})$ achieved in patients after daily oral administration of $4 \mathrm{mg}$ RSG, $30 \mathrm{mg}$ PIO, or 400 mg TRO [43-45]; or (2) within the pharmaco- 
logical range (25 and $50 \mu \mathrm{mol} / \mathrm{l})$. Vascular cells exposed to these concentrations of TZDs were fully viable (as tested by trypan blue exclusion; data not shown).

In conclusion, our data demonstrate that thiazolidinediones exert antiproliferative activity in all types of vascular cells studied. Such data are of importance, since vascular injury, induced by a proatherogenic diabetic milieu [46-48], is characterised by accelerated proliferation of vascular cells (including endothelial and smooth muscle cells) preceding the manifestation of both macrovascular and microvascular complications (e.g. proliferative retinopathy, atherosclerosis). The observed direct antiproliferative actions of thiazolidinediones in vascular cells (1) seem to be independent of PPAR $\gamma$ activation and thus from their reported insulin-sensitising potential, but (2) correlate with lactate release, possibly due to inhibition of mitochondrial function on the level of complex I.

Acknowledgements We thank Johnson \& Johnson Pharmaceutical Research \& Development, L.L.C. (Raritan, NJ, USA) and Pfizer (Ann Arbor, MI, USA) for generously providing compounds.

The authors thank Jörg Leers (Karolinska Institute, Department of Biosciences at Novum, Huddinge, Sweden) for generously providing the PPRE construct.

M. Roden received honoraries for lectures from GlaxoSmithKline and Takeda.

\section{References}

1. Saltiel AR, Olefsky JM (1996) Thiazolidinediones in the treatment of insulin resistance and type II diabetes. Diabetes 45:1661-1669

2. Brunmair B, Staniek K, Gras F et al (2004) Thiazolidinediones, like metformin, inhibit respiratory complex I: a common mechanism contributing to their antidiabetic actions? Diabetes 53: $1052-1059$

3. Delerive P, Martin-Nizard F, Chinetti G et al (1999) Peroxisome proliferator-activated receptor activators inhibit thrombin-induced endothelin-1 production in human vascular endothelial cells by inhibiting the activator protein-1 signaling pathway. Circ Res 85:394-402

4. Marx N, Bourcier T, Sukhova GK, Libby P, Plutzky J (1999) PPARgamma activation in human endothelial cells increases plasminogen activator inhibitor type-1 expression: PPARgam$\mathrm{ma}$ as a potential mediator in vascular disease. Arterioscler Thromb Vasc Biol 19:546-551

5. Kato K, Satoh H, Endo Y et al (1999) Thiazolidinediones downregulate plasminogen activator inhibitor type 1 expression in human vascular endothelial cells: a possible role for PPARgamma in endothelial function. Biochem Biophys Res Commun 258: 431-435

6. Jackson SM, Parhami F, Xi XP et al (1999) Peroxisome proliferator-activated receptor activators target human endothelial cells to inhibit leukocyte-endothelial cell interaction. Arterioscler Thromb Vasc Biol 19:2094-2104

7. Chen NG, Sarabia SF, Malloy PJ, Zhao XY, Feldmann D, Reaven GM (1999) PPARgamma agonists enhance human vascular endothelial adhesiveness by increasing ICAM-1 expression. Biochem Biophys Res Commun 263:718-722

8. Xin X, Yang S, Kowalski J, Gerritsen ME (1999) Peroxisome proliferator-activated receptor $\gamma$ ligands are potent inhibitors of angiogenesis in vitro and in vivo. J Biol Chem 274:9116-9121

9. Panigrahy D, Singer S, Shen LQ et al (2002) PPAR $\gamma$ ligands inhibit primary tumor growth and metastasis by inhibiting angiogenesis. J Clin Invest 110:923-932
10. Hsueh WA, Jackson S, Law RE (2001) Control of vascular cell proliferation and migration by PPAR- $\gamma$ : a new approach to the macrovascular complications of diabetes. Diabetes Care 24: 392-397

11. Murata T, He S, Hangai M et al (2000) Peroxisome proliferatoractivated receptor- $\gamma$ ligands inhibit choroidal neovascularization. Invest Ophthalmol Vis Sci 41:2309-2317

12. Murata T, Hata Y, Ishibashi T et al (2001) Response of experimental retinal neovascularization to thiazolidinediones. Arch Ophthalmol 119:709-717

13. Marx N, Mach F, Sauty A et al (2000) Peroxisome proliferatoractivated receptor-gamma activators inhibit IFN-gamma-induced expression of the T cell-active CXC chemokines IP-10, Mig, and I-TAC in human endothelial cells. J Immunol 164 6503-6508

14. Wang M, Wise SC, Leff T, Su T-Z (1999) Troglitazone, an antidiabetic agent, inhibits cholesterol biosynthesis through a mechanism independent of peroxisome proliferator-activated receptor- $\gamma$. Diabetes 48:254-260

15. Brunmair B, Gras F, Neschen S et al (2001) Direct thiazolidinedione action on isolated rat skeletal muscle fuel handling is independent of peroxisome proliferator-activated receptor- $\gamma$ mediated changes in gene expression. Diabetes 50:2309-2315

16. Reginato MJ, Bailey ST, Krakow SL et al (1998) A potent antidiabetic thiazolidinedione with unique peroxisome proliferator-activated receptor $\gamma$-activating properties. J Biol Chem 273:32679-32684

17. Artwohl M, Graier WF, Roden M et al (2003) Diabetic LDL triggers apoptosis in vascular endothelial cells. Diabetes 52: $1240-1247$

18. Artwohl M, Roden M, Waldhäusl W, Freudenthaler A, Baumgartner-Parzer SM (2004) Free fatty acids trigger apoptosis and inhibit cell cycle progression in human vascular endothelial cells. FASEB J 18:146-148

19. Artwohl M, Roden M, Hölzenbein T, Freudenthaler A, Waldhäusl W, Baumgartner-Parzer SM (2002) Modulation by leptin of proliferation and apoptosis in vascular endothelial cells. Int J Obesity Relat Metab Disord 26:577-580

20. Grant MB, Guay C (1991) Plasminogen activator production by human retinal endothelial cells of non-diabetic and diabetic origin. Invest Ophthalmol Vis Sci 32:53-64

21. Nayak RC, Berman AB, George KL, Eisenbarth GS, King GL (1988) A monoclonal antibody (3G5)-defined ganglioside antigen is expressed on the surface of microvascular pericytes. J Exp Med 167:1003-1015

22. Bull AW, Steffensen KR, Leers J, Rafter JJ (2003) Activation of PPAR $\gamma$ in colon tumor cell lines by oxidized metabolites of linoleic acid, endogenous ligands for PPAR $\gamma$. Carcinogenesis 24:1717-1722

23. Engel PC, Jones JB (1978) Causes and elimination of erratic blanks in enzymatic metabolic assays involving the use of $\mathrm{NAD}^{+}$ in alkaline hydrazine buffers: improved conditions for the assay of L-glutamate, L-lactate and other metabolites. Anal Biochem $88: 475-484$

24. de Dios ST, Bruemmer D, Dilley RJ et al (2003) Inhibitory activity of clinical thiazolidinediones peroxisome proliferator activating receptor- $\gamma$ ligands toward internal mammary artery, radial artery and saphenous vein smooth muscle cell proliferation. Circulation 107:2548-2550

25. Herzinger T, Reed SI (1998) Cyclin D3 is rate limiting for the $\mathrm{G}_{1} / \mathrm{S}$ phase transition in fibroblasts. J Biol Chem 273:1495814961

26. Sherr CJ (1995) D-type cyclins. Trends Biochem Sci 20:187190

27. Alberts B, Bray D, Lewis J, Raff M, Roberts K, Watson JD (1994) The cell-division cycle. In: Alberts B, Bray D, Lewis J, Raff M, Roberts K, Watson JD (eds) Molecular biology of the cell. Garland Publishing, New York, pp 863-910

28. DeGregori J, Kowalik T, Nevins JR (1995) Cellular targets for activation by the E2F1 transcription factor include DNA synthesis- and $\mathrm{G}_{1} / \mathrm{S}$-regulatory genes. Mol Cell Biol 15:4215-4224 
29. Weinberg RA (1996) E2F and cell proliferation: a world turned upside down. Cell 85:457-459

30. Weinberg RA (1995) The retinoblastoma protein and cell cycle control. Cell 81:323-330

31. Wakino S, Kintscher U, Kim S, Yin F, Hsueh WA, Law RE (2000) Peroxisome proliferator-activated $\gamma$ ligands inhibit retinoblastoma phosphorylation and $\mathrm{G}_{1} \rightarrow \mathrm{S}$ transition in vascular smooth muscle cells. J Biol Chem 275:22435-22441

32. Dotto GP (2000) p2 $1^{\text {WAF1/Cip1 }}$ : more than a break to the cell cycle? Biochim Biophys Acta 1471:M43-M56

33. Auwerx J (1999) PPAR $\gamma$, the ultimate thrifty gene. Diabetologia 42:1033-1049

34. Berger J, Bailey P, Biswas C et al (1996) Thiazolidinediones produce a conformational change in peroxisomal proliferatoractivated receptor- $\gamma$ : binding and activation correlate with antidiabetic actions in $\mathrm{db} / \mathrm{db}$ mice. Endocrinology 137:41894195

35. Kersten S, Desvergne B, Wahli W (2000) Roles of PPARs in health and disease. Nature 405:421-424

36. Coates G, Nissim I, Battarbee H, Welbourne T (2002) Glitazones regulate glutamine metabolism by inducing a cellular acidosis in MDCK cells. Am J Physiol 283:E729-E737

37. Dello Russo C, Gavrilyuk V, Weinberg G et al (2003) Peroxisome proliferator-activated receptor $\gamma$ thiazolidinedione agonists increase glucose metabolism in astrocytes. J Biol Chem 278: 5828-5836

38. Ceaser EK, Ramachandran A, Levonen A-L, Darley-Usmar V (2003) Oxidized low density-lipoprotein and 15-deoxy- $\Delta^{12,14}$ -prostaglandin $\mathrm{J}_{2}$ increase mitochondrial complex I activity in endothelial cells. Am J Physiol Heart Circ Physiol 285:H2298H2308
39. Green K, Brand MD, Murphy MP (2004) Prevention of mitochondrial oxidative damage as a therapeutic strategy in diabetes. Diabetes 53(Suppl 1):S110-S118

40. Nishikawa T, Edelstein D, Du XL et al (2000) Normalizing mitochondrial superoxide production blocks three pathways of hyperglycaemic damage. Nature 404:787-790

41. Spitaler MM, Graier WF (2002) Vascular targets of redox signalling in diabetes mellitus. Diabetologia 45:476-494

42. Fukunaga Y, Itoh H, Doi K et al (2001) Thiazolidinediones, peroxisome proliferator-activated receptor $\gamma$ agonists, regulate endothelial cell growth and secretion of vasoactive peptides. Atherosclerosis 158:113-119

43. Gilles PS, Dunn CJ (2000) Adis new drug profile-Pioglitazone. Drugs 60:333-343

44. Niemi M, Backman JT, Granfors M, Laitila J, Neuvonen M, Neuvonen PJ (2003) Gemfibrozil considerably increases the plasma concentrations of rosiglitazone. Diabetologia 46:1319 1323

45. Loi CM, Randinitis EJ, Vassos AB, Kazierad DJ, Koup JR, Sedman AJ (1997) Lack of effect of type II diabetes on the pharmacokinetics of troglitazone in a multiple-dose study. J Clin Pharmacol 37:1114-1120

46. Boeri D, Maiello M, Lorenzi M (2001) Increased prevalence of microthrombosis in retinal capillaries of diabetic individuals. Diabetes 50:1432-1439

47. Ruderman NB, Cacicedo JM, Itani S et al (2003) Malonyl-CoA and AMP-activated protein kinase (AMPK): possible links between insulin resistance in muscle and early endothelial damage in diabetes. Biochem Soc Trans 31:202-206

48. Ruderman NB, Williamson JR, Brownlee M (1992) Glucose and diabetic vascular disease. FASEB J 6:2905-2914 